\title{
Synthesis and structural studies of a new class of quaternary ammonium salts, which are derivatives of cage adamanzane type aminal 1, 3, 6, 8-tetraazatricyclo[4.3.1.1 ${ }^{3,8}$ ] undecane (TATU)
}

\author{
Augusto Rivera ${ }^{1 *}$, John Sadat-Bernal ${ }^{1}$, Jaime Ríos-Motta ${ }^{1}$, Michal Dušek ${ }^{2}$ and Lukáš Palatinus ${ }^{2}$
}

\begin{abstract}
Background: Novel mono N-alkyl quaternary ammonium salts (3a-f) were prepared using the Menschutkin reaction from the cage adamanzane type aminal 1,3,6,8-tetraazatricyclo[4.3.1.1.8.8] undecane (TATU) and alkyl iodides, such as methyl, ethyl, propyl, butyl, pentyl and hexyl iodide (2a-f), in dry acetonitrile at room temperature.

Results: The structures of these new quaternary ammonium salts were established using various spectral and electrospray ionization mass spectrometry (ESI-MS) analyses. Compound (3b) was also analyzed using X-ray crystallography.

Conclusion: It was noted that alkyl chain length did not significantly affect the reaction because all employed alkyl iodide electrophiles reacted in a similar fashion with the aminal $\mathbf{1}$ to produce the corresponding mono $\mathrm{N}$ quaternary ammonium salts, which were characterized by spectroscopic and analytical techniques.
\end{abstract}

\section{Background}

Cage aminals of the adamanzane type are tricyclic tertiary tetraamines, which can act as bases or as nucleophiles. The main subject of research in our laboratory (Universidad Nacional, Bogotá) is the reactivity of these polyamine bases toward nucleophiles and electrophiles. In recent years, we became interested in the cage aminal 1,3,6,8-tetraazatricyclo[4.3.1.1 $\left.{ }^{3,8}\right]$ undecane (TATU, $\mathbf{1}$ ) because of its interesting molecular structure, which contains two pairs of non-equivalent nitrogen atoms [1-6]. To the best of our knowledge, only two available studies in the literature have investigated reactions of $\mathbf{1}$ with electrophilic reagents [4,5], but its nucleophilicity has not been investigated. To gain further insight into the nucleophilic properties of this aminal, which has four active nucleophilic centers and, consequently, offers a series of alternative possibilities for alkylation, we reacted $\mathbf{1}$ with several primary alkyl halides using the Menschutkin reaction, i.e., $\mathrm{N}$-alkylation of tertiary

\footnotetext{
* Correspondence: ariverau@unal.edu.co

'Departamento de Química, Universidad Nacional de Colombia, Ciudad

Universitaria, Carrera 30 No. 45-03, Bogotá D.C., Colombia

Full list of author information is available at the end of the article
}

amines with haloalkyls [7]. We found that no reaction occurred when $\mathrm{N}$-alkylation was attempted using alkyl bromides and chlorides. Compound $\mathbf{1}$ reacts with alkyl iodides in dry acetonitrile at room temperature to produce mono $\mathrm{N}$-alkyl ammonium quaternary salts (3a-f) (Scheme 1) with a yield of approximately $80-90 \%$. Attempts to quaternize more than one nitrogen atom failed, even in the presence of excess alkylating agent, and only one of the four possible quaternary ammonium derivatives was obtained. We attribute this behavior to the stereoelectronic factors that govern the N-C-N (aminal) group. As prior studies have demonstrated [8], the activity of amines in quaternization with alkyl halides primarily depends on the spatial structure and induction effects of substituents at the nitrogen atom. Other interactions, such as the anomeric effect, have been observed to produce changes in the molecular geometry of aminals. Molecular orbital studies at the $a b$ initio level implicate $\left(\mathrm{n}_{\mathrm{N}} \rightarrow \sigma^{*}{ }_{\mathrm{C}-\mathrm{N}}\right)$ type interactions between a lone pair on $\mathrm{N}$ and an antiperiplanar $\sigma^{*}$ orbital of the adjacent $\mathrm{C}-\mathrm{N}$ bond as being responsible for the anomeric effect [9]. In fact, in N-protonated aminals, the existence of a strong anomeric effect has been 
clearly established $[10,11]$. Our results suggest that the anomeric effect evidenced by the shortening and lengthening of N-C-N bond lengths and distortion of the C$\mathrm{N}-\mathrm{C}$ bond angles increases the $p$ character of noncharged nitrogens and reduces the N-pyramidality, thereby making the nitrogen less nucleophilic [12]. In summary, these quaternary ammonium salts provide new evidence characterizing anomeric effects in aminals that possess one nitrogen atom with a full positive charge. These results demonstrated that the degree of nucleophilicity of the specific nitrogen atoms varies and increases with higher $\mathrm{sp}^{3}$ character. Compounds (3a-f) were characterized with ESI-MS, FT-IR, and ${ }^{1} \mathrm{H}$ and ${ }^{13} \mathrm{C}$ NMR spectral studies. Unequivocal assignments of methylene hydrogens was achieved by ${ }^{1} \mathrm{H}-{ }^{1} \mathrm{H}$ COSY experiments. The structure of compound $\mathbf{3 b}$ was confirmed by a structural study using X-ray crystallography.

Quaternary ammonium salts have multiple uses in industry, in laboratories and in the household. These compounds act as disinfectants, antiseptic agents, surfactants, fabric softeners, corrosion inhibitors, emulsifiers and antistatic agents (e.g., in shampoos). In organic syntheses, these compounds are used as phase transfer catalysts for a wide range of organic reactions involving immiscible solvent systems [13]. In recent years, interest in ammonium salts has concerned their utilization in templating organic molecules in the synthesis of zeolites, e.g., in photoreactions of chirally modified zeolites [14], in the synthesis and mechanism of decomposition study of triazenes [15], in the obtention of ionomers with photoluminescent properties [16] and for obtaining new Rh and Ag complex [17], and the use of these ammonium salts as ionic liquids and energetic molecular compounds [18]. These quaternary ammonium salts can react with alkyl halides, leading to the formation of new ammonium salts, which are promising candidates for new zeolite templates and energetic molecular compounds.

\section{Results and Discussion}

Reaction of $\mathbf{1}$ with alkyl iodides $\mathbf{2 a - f}$ produced 3a-f in good to excellent yields using the standard protocols for

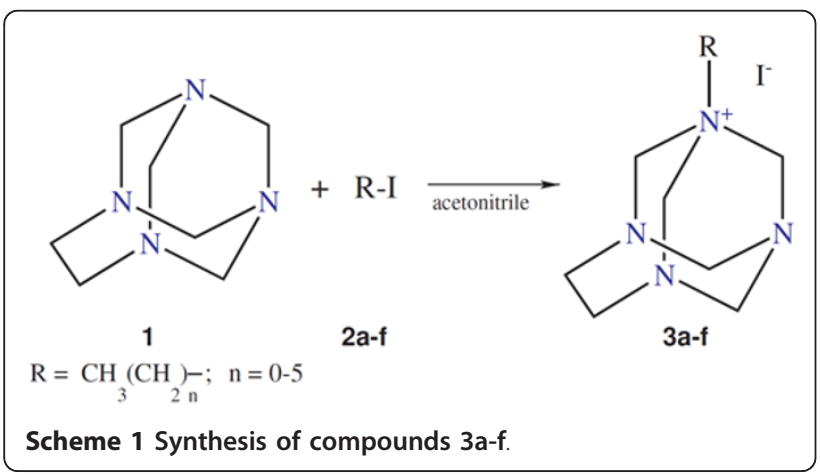

the alkylation of amines. The reaction products were separated by precipitation from dry acetonitrile solution. In the FT-IR spectra of 3a-f (in $\mathrm{KBr}$ ), alkyl chains showed absorption bands at $2960-2830 \mathrm{~cm}^{-1}$ for asymmetric and symmetric stretching vibrations. Absorption bands at $1148-1136 \mathrm{~cm}^{-1}$, which were related to symmetric $\mathrm{C}-\mathrm{N}$ stretching vibrations, were observed. The signals at the masses of 169.1449, 183.1587, 197.1730, 211.1923, 225.2120, 239.2291, and 253.2441 in the ESIMS spectra in the positive ion mode were assigned to the respective charged quaternary ammonium ions of compounds 3a-f. The fragmentation patterns of these spectra were found to be similar to one another.

A close inspection of the ${ }^{1} \mathrm{H}$ NMR spectral patterns for the aminalic protons of 3a-f suggests that a mono$\mathrm{N}$-alkyl ammonium salt was obtained. The quaternary ammonium group reduced the symmetry of $\mathbf{3 a - f}$ relative to $\mathbf{1}$, making them readily differentiated from $\mathbf{1}$ by ${ }^{1} \mathrm{H}$ NMR. The positive charge on one of the nitrogen atoms is evident in the ${ }^{1} \mathrm{H}$ NMR spectra of $\mathbf{3 a}-\mathbf{f}$, which exhibit signals that are shifted downfield with more complex splitting patterns. The largest effect was observed for the $\mathrm{H}_{\mathrm{d}}$ proton, which appears at approximately 4.83 $\mathrm{ppm}$, while the corresponding signal in the ${ }^{1} \mathrm{H}$ NMR spectrum of compound 1 resonates at $3.62 \mathrm{ppm}$ [3]. The characteristic signals of aminal cage structure in the ${ }^{1} \mathrm{H}$ NMR spectra of $\mathbf{3 a - f}$ are grouped into four AB spin systems belonging to the four methylene bridgehead protons $\left(\mathrm{H}_{\mathrm{a}}, \mathrm{H}_{\mathrm{b}}, \mathrm{H}_{\mathrm{c}}\right.$ and $\left.\mathrm{H}_{\mathrm{d}}\right)$ and two singlets around $3.43\left(\mathrm{NCH}_{2} \mathrm{CH}_{2} \mathrm{~N}\right)$ and $4.82 \mathrm{ppm}\left(\mathrm{NCH}_{2} \mathrm{~N}\right)$, which can be observed in the low field region of the spectra. The homonuclear coupling constant value indicated that doublets form $A B$ pairs. However, the $1 \mathrm{D}$ spectrum was not sufficient for a complete assignment. Figure 1 shows the ${ }^{1} \mathrm{H}$ NMR of $\mathbf{3 b}$ as an example.

Because there is long-range coupling between hydrogen atoms that are in the $\mathrm{W}$ conformation, the ${ }^{1} \mathrm{H}$ NMR spectrum alone was not definitive in assigning all protons. ${ }^{1} \mathrm{H}_{-}{ }^{1} \mathrm{H}$ COSY experiments allowed the assignment of the signals of all of the $\mathrm{W}$-positioned hydrogen atoms. For instance, in the ${ }^{1} \mathrm{H}-{ }^{1} \mathrm{H}-\mathrm{COSY}$ spectrum (Figure 2), one cross peak involved the W-coupling between $\mathrm{H}_{\mathrm{a}}$ hydrogens of methylene groups 7 and 10, and the $\mathrm{H}_{\mathrm{d}}$ hydrogens of methylene groups 2 and 11 appears between the doublets at $4.00 \mathrm{ppm}$ and $4.83 \mathrm{ppm}$. Therefore, the signals at 4.64 and $4.83 \mathrm{ppm}$ can be unequivocally assigned to $\mathrm{H}_{c}$ and $\mathrm{H}_{\mathrm{d}}$ protons, respectively.

The structures of 3a-f were determined from the correlations found in the ${ }^{1} \mathrm{H}_{-}{ }^{1} \mathrm{H}$ COSY, HMQC and $\mathrm{HMBC}$ contour plots. The number of signals observed indicates that $\mathrm{C}_{2 v}$ symmetry is not maintained in the cage structure. Instead, the polycyclic structure adopts a $\mathrm{C}_{s}$ symmetry. This conformation cannot explain the NMR results because the ethylene bridge of $\mathbf{3 a - f}$ is virtually 


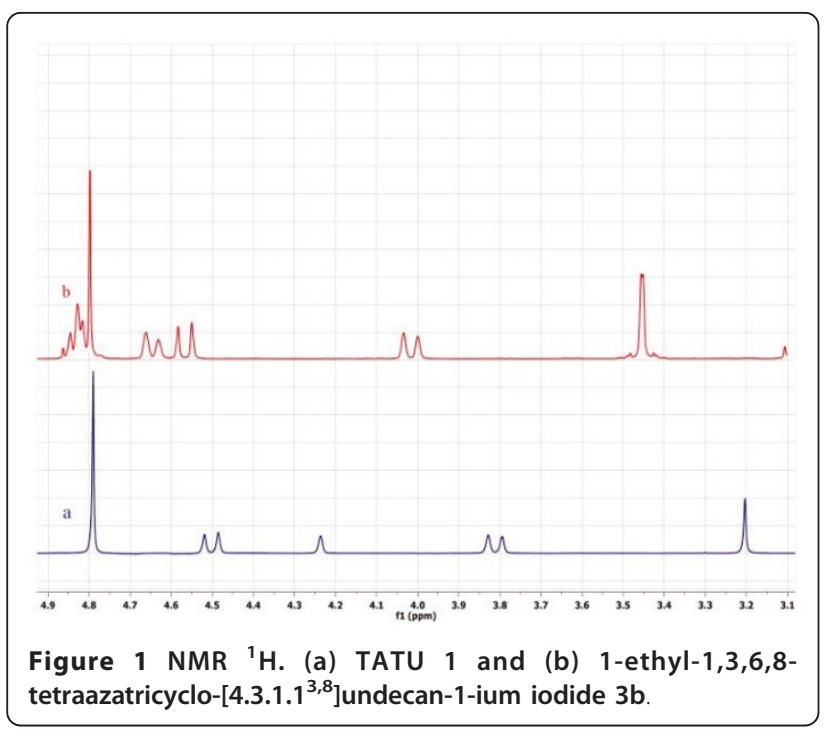

symmetrical; however, a single resonance at $3.43 \mathrm{ppm}$ is observed, and the doublet or triplet expected for the ethylene bridge protons is collapsed to a single line. The equivalence of these protons can be explained in two different ways, either by rapid interconverting conformers of the 1,3,5-triazepane ring, which can adopt two conformations (Figure 3) on the NMR time scale, or by the virtual chemical equivalence of these protons. In the case of the aminal cage structure, some conformational freedom for small rotations of the ethylene bridge [19]. To test this hypothesis, we conducted single-point energy calculations of the $S_{4}$ and $D_{2 d}$ ethylene residue conformations of $\mathbf{1}$ using a Gaussian software package [20] at the Hartree-Fock level with a $6-31 G^{*}$ basis set, but our results revealed that the $S_{4}$ conformation is 64.0 $\mathrm{kcal} / \mathrm{mol}$ higher in energy than is the $D_{2 d}$ conformation.

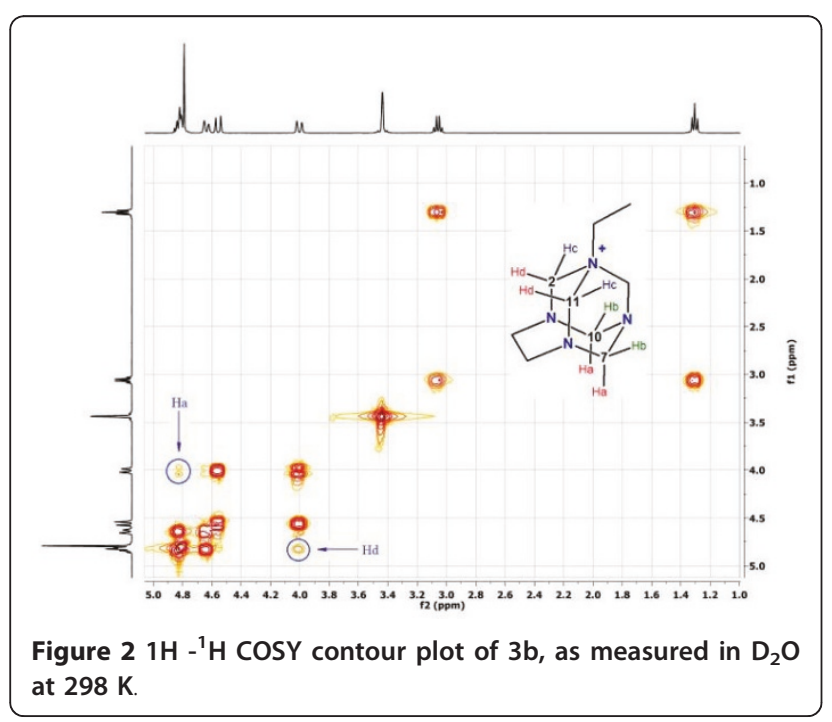

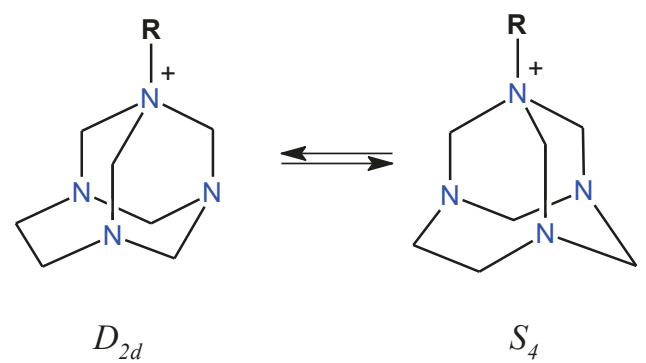

Figure $3 D_{2 d}$ and $S_{4}$ ethylene residue conformation of the aminal cage.

The higher-energy conformer could be avoided at room temperature, and the equivalence could be caused by close shifts of the signals of the $\mathrm{NCH}_{2} \mathrm{CH}_{2} \mathrm{~N}$ fragment.

Using X-ray crystallography, structural investigation of aminal cage structures indicated an almost planar ethylene bridge with a $D_{2 d}$ conformation and large distortions of the N-C-N and the C-N-C bond angles $[19,21]$. We expected that the incorporation of these alkyl substituents would not affect the structure of the aminal cage. Several attempts were made to recrystallize the products from a warm saturated water solution, but only single crystals of compound $\mathbf{3 b}$ could be grown (Table 1).

The molecular structure and atom-numbering scheme are shown in Figure 4. The asymmetric unit consists of one quaternary ammonium cation and three iodide anions. The iodide atoms are located in specific positions such that the sum formula contains one iodide and one quaternary ammonium cation. The atom numbering diagram shows that the cation adopts a $D_{2 d}$ conformation with a torsion angle in the ethylene bridge fragment of $-4.2(3)^{\circ}$. Within the aminal cage structure, the bond distances are comparable to the bond distances in the 1,3,6,8-tetraazatricyclo[4.3.1.1.1 $1^{3,8}$ undecan1 -ium cation 1 [6]. C-N bond distances provide structural evidence for a strong anomeric effect, due to the presence of the quaternary nitrogen atom, which distorts the aminal cage. The $\mathrm{C}-\mathrm{N}$ bond lengths involving the quaternary $\mathrm{N} 3$ atom are significantly longer than the other $\mathrm{C}-\mathrm{N}$ bond lengths. The anomeric effect is also responsible for the distortion of the $\mathrm{C}-\mathrm{N} 1-\mathrm{C}$ bond angles with respect to the neutral aminal cage structure [2]. The charge of the N3 atom leads to an increase in the bond order of the N1-C4 bond and makes the C4N1-C2 and C4-N1-C1 angles greater than the comparable angles in the uncharged aminal cage by $2^{\circ}$. Also, the presence of this positive charge has a strong and direct influence on the reactivity of the aminal cage. In fact, our preliminary analysis of the chemical reactivity of 3a-f with phenols showed that the rate of reaction is greater than that of TATU. Furthermore, the Fukui 
Table 1 Crystal data and structure refinement for 1-ethyl1,3,6,8-tetraaza-tricyclo[4.3.1.1 ${ }^{3,8}$ ] undecan-1-ium iodide $3 \mathbf{b}$

\begin{tabular}{ll}
\hline Empirical formula & $\mathrm{C}_{9} \mathrm{H}_{19} \mathrm{~N}_{4} \cdot \mathrm{l}$ \\
Formula weigth & 310.18 \\
Temperature & $120 \mathrm{~K}$ \\
Wavelenght & $0.71070 \AA$ \\
Crystal system, space group & Trigonal, $R 3$ \\
Unit cell dimensions & $a=12.8935(3) \AA$ \\
& $b=12.8935(3) \AA$ \\
& $\mathrm{C}=18.4328(4) \AA$ \\
& $\alpha=90^{\circ}$ \\
& $\beta=90^{\circ}$ \\
& $\gamma=120^{\circ}$ \\
Volume & $2653.77(10) \AA^{3}$ \\
Z, Calculated density & $9,1.746 \mathrm{~g} / \mathrm{cm}$ \\
Absorption coefficient & $2.687 \mathrm{~mm} \mathrm{~m}^{-1}$ \\
F (0 0 0) & 1386 \\
Crystal size & $0.42 \times 0.34 \times 0.25 \mathrm{~mm}$ \\
$\theta$ range for data collection & $3.1-26.3$ \\
Max/min. indices $h, k, l$ & $-16 / 16,-16 / 16,-22 / 22$ \\
Reflections collected/unique & $9196 / 2386[R($ int $)=0.014]$ \\
$\theta_{\text {Max }}\left({ }^{\circ}\right) /$ Completeness (\%) & $26.31 / 199.17$ \\
Refinement method & Full-matrix least-squares on $F^{2}$ \\
Data/restrains/parameters & $2386 / 0 / 127$ \\
Goodness-of-fit on $F^{2}$ & 1.02 \\
Final $R$ indices[l $>3 \sigma]$ & $R 1=0.0106, w R 2=0.0317$ \\
$R$ indices (all data) & $R 1=1.06, w R 2=3.17$ \\
Largest diff. peak and hole & 0.19 and -0.13 e $\AA^{-3}$ \\
\hline &
\end{tabular}

index was used to localize possible sites in which chemical reactivity is enhanced. The Fukui index for $\mathbf{3 b}$ suggests that the most reactive site for nucleophilic attack in the cation is C-4 (Table 2).

Thus, the formation of the carbon-nitrogen bond increases the reactivity compared with TATU. The

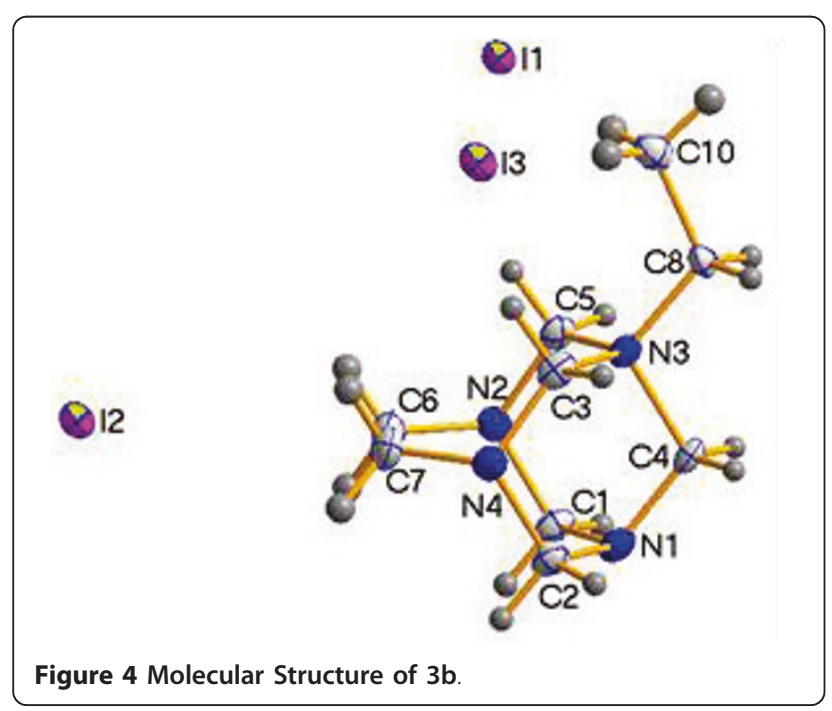

Table 2 Fukuy index by $\mathbf{3 b}$

\begin{tabular}{llll}
\hline Entry & B3LYP/6-31G & B3LYP/6-311G & MPW/6311-G \\
\hline C-1 & 0.051 & 0.056 & 0.014 \\
C-2 & 0.053 & 0.059 & 0.014 \\
C-3 & 0.074 & 0.131 & 0.005 \\
C-4 & 0.018 & 0.284 & 0.013 \\
C-5 & 0.077 & 0.138 & 0.003 \\
C-8 & 0.131 & 0.128 & 0.006 \\
\hline
\end{tabular}

Fukui index results (Table 2) are consistent with the electron density isosurface (with an isovalue of 0.02) for 3b (Figure 5) where an attractive interaction results in negative potential energy (colored in dark blue).

The X-ray diffraction experiments showed that the ethyl group adopts a preferential orientation with respect to the ethylene bridge. Theoretical calculations were performed for this compound in order to estimate the more stable geometries that were possible. The equilibrium geometries of the low-energy conformers of $\mathbf{3 b}$ were fully optimized at the HF level of theory with the 6-31G(d) basis set. In both conformers, the ethyl group is coplanar with the mean plane of the aminal cage. However, the rotational energy barrier is only $28.21 \mathrm{~kJ} /$ mol, suggesting a 'rapid rotation' of the ethyl group around the N3-C8 bond. The organization of the crystal packing for the title compound exhibits a network interconnecting through $\mathrm{C}-\mathrm{H}$...I and $\mathrm{C}-\mathrm{H}$...C short contacts. The anion is inserted between three cations, thereby forming a supramolecular motif by C-H...I (3.137 $\AA$ ) short contact (Figure 6) with a distance shorter than the sum of the Van der Waals radii of $\mathrm{I}$ and $\mathrm{H}(\mathrm{rI}=2.20 \AA)$.

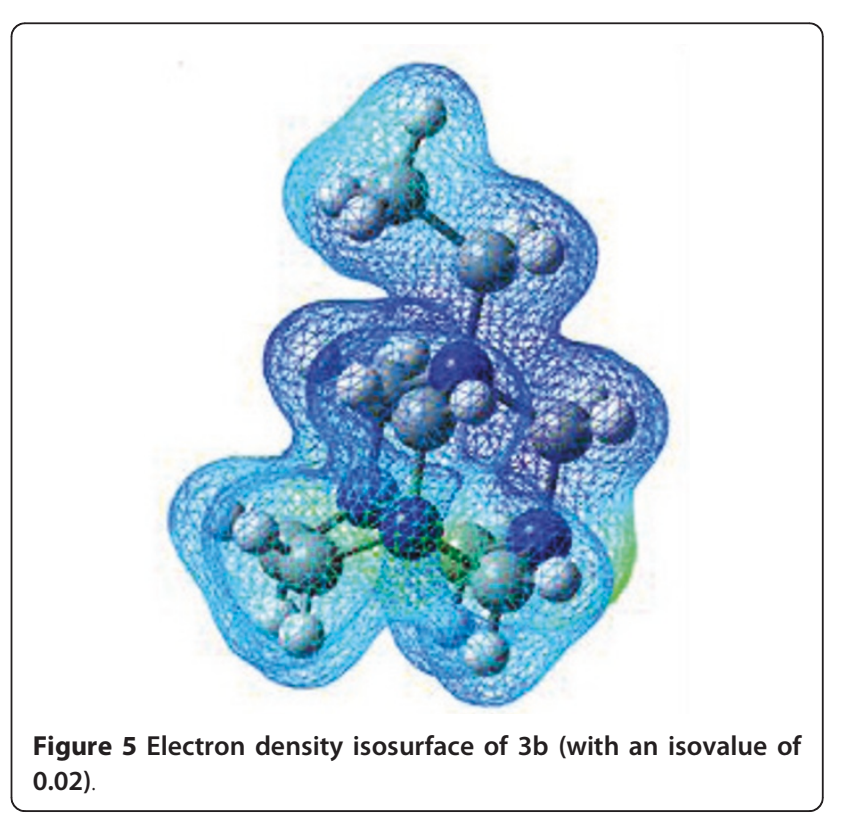




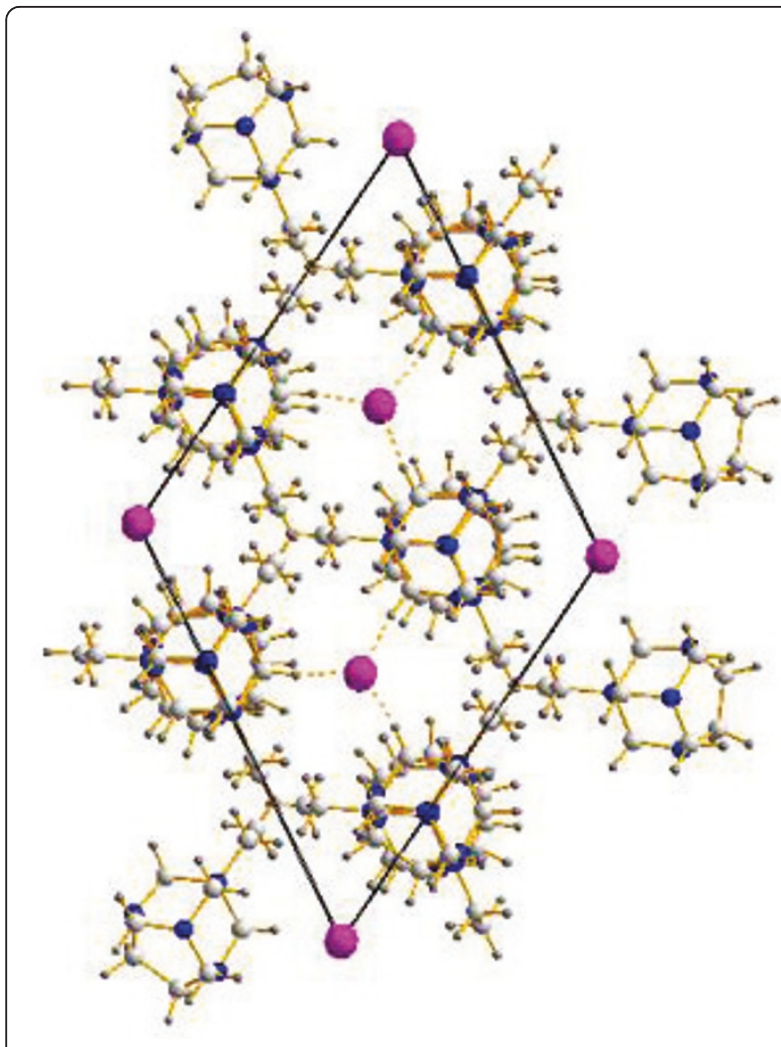

Figure 6 Crystal packing of $3 b$.

The structure solution was complicated by twinning and by the presence of heavy atoms, namely iodine atoms, which made it difficult to recognize the organic molecule and disentangle the twinning. In the diffraction pattern, every third layer contains strong reflections, while the intervening layers are much weaker. This phenomenon is observed because the iodine atoms occupy positions that make a 9-fold smaller subcell, and the true cell is created only by the organic moieties. The crystal used for the structure solution was an especially well-ordered one in which the superstructure reflections are sharp and can be integrated. The structure has a layered structure along $\mathrm{c}$ with layers of organic molecules separated by layers of iodine with hexagonal symmetry. The organic molecules are aligned one on the top of one another, and, between them, there are nearly empty channels that are filled by the ethyl groups of the molecules. It is not surprising that, under non-equilibrium crystallization conditions, the layers tend to stack in a disordered fashion, and, sometimes, the next layer is stacked such that its molecules lie above the channels in the bottom layer. If such a stacking fault occurs frequently, we obtain a completely disordered crystal with, on average, nine times a smaller unit cell. For less frequently occurring stacking faults, the crystal can be better modeled as a twin. This property is observed in the case of the current structure. The twinning law is a mirror plane perpendicular to a (or, equivalently, b).

\section{Conclusions}

It was noted that alkyl chain length did not significantly affect the reaction because all employed alkyl iodide electrophiles reacted in a similar fashion with the aminal 1 to produce the corresponding mono $\mathrm{N}$-quaternary ammonium salts, which were characterized by spectroscopic and analytical techniques. Furthermore, 1 only reacts with alkyl iodides, and the quaternization occurs regioselectively on the nitrogen with major $\mathrm{sp}^{3}$ character, which prevents its further alkylation even in a large excess of electrophile. The elucidation of the structure of compound $\mathbf{3 b}$, both in the solid state and in solution, has revealed that $n N-\sigma{ }^{*} \mathrm{CH}_{2}-\mathrm{N}_{3} \mathrm{R}^{+}$orbital overlap confirms that an anomeric effect is present in the ammonium salt. This straightforward, one-step process provides a convenient preparative method for mono- $N$ alkylated quaternary ammonium salts and could be of interest to investigate the kinetic and thermodynamic properties of the Menschutkin reaction.

\section{Experimental}

\section{General and Instrumentation}

NMR spectra were performed in $\mathrm{D}_{2} \mathrm{O}$ on a Bruker Avance 400 operating at $400.13 \mathrm{MHz}\left({ }^{1} \mathrm{H}\right)$, and $100.4 \mathrm{MHz}\left({ }^{13} \mathrm{C}\right)$ at room temperature; chemical shifts were referenced to deuterium $\left({ }^{1} \mathrm{H}\right)$ and to external $\mathrm{CDCl}_{3}\left({ }^{13} \mathrm{C}\right)$. Infrared spectra were recorded as $\mathrm{KBr}$ discs on a Perkin-Elmer Paragon FT-IR instrument in the range of $4000-600 \mathrm{~cm}^{-1}$. MS-ESI mass spectra were obtained with a Micromass Technologies-LCT Premier XE Waters; melting points were taken in capillaries on an Electrothermal 9100 melting point apparatus and are presented without correction. Compound 1 was synthesized according to a previously reported procedure [1]. Solvents and reagents were distilled before use. Crystals suitable for single-crystal X-ray determination were produced by keeping a solution of $\mathbf{3 b}$ in water for several days at room temperature.

\section{General procedure for the synthesis of compounds 3a-f}

To a solution of $1(0.154 \mathrm{~g}, 1.0 \mathrm{mmol})$ in dry acetonitrile $(5 \mathrm{~mL})$ was added an equivalent amount $(1.0 \mathrm{mmol})$ of the respective alkyl iodide (2a-f). The reaction mixture was stirred at room temperature for $5 \mathrm{~h}$ until a precipitate was observed. The resultant precipitate was filtered under vacuum, washed successively with chloroform and dried in vacuo (Scheme 1).

1-methyl-1,3,6,8-tetraazatricyclo[4.3.1.1 $1^{3,8}$ undecan-1-ium iodide (3a)

Was isolated as a white solid highly hygroscopic, $(0.216 \mathrm{~g}$, $73 \%)$. M.p. $=117-118.3^{\circ} \mathrm{C}$ (decomposition), FT-IR (KBr) 
$\nu_{\max }: 2994,2974,2946,1473,1454,1405,1387,1347$, $1321,1296,1256,1235,1158,1128,1114,1044,1022$, 993, 979, 965, 925, 881, 843, 813, 771, 737, 694, 656, 582, $529,497,471,455,423 \mathrm{~cm}^{-1} .{ }^{1} \mathrm{H}$ NMR $\left(400 \mathrm{MHz}, \mathrm{D}_{2} \mathrm{O}\right) \delta$ (ppm): 2.64 ( $s, 3 \mathrm{H}, \mathrm{H}-12), 3.42(s, 4 \mathrm{H}, \mathrm{H}-4$ and $\mathrm{H}-5), 3.97$ $(d, J=16.0 \mathrm{~Hz}, 2 \mathrm{H}, \mathrm{H}-7 \mathrm{a}$ and $\mathrm{H}-10 \mathrm{a}), 4.52(d, J=12.0$ $\mathrm{Hz}, 2 \mathrm{H}, \mathrm{H}-2 \mathrm{c}$ and $\mathrm{H}-11 \mathrm{c}), 4.56(d, J=16.0 \mathrm{~Hz}, 2 \mathrm{H}, \mathrm{H}-7 \mathrm{~b}$ and $\mathrm{H}-10 \mathrm{~b}), 4.81(s, 2 \mathrm{H}, \mathrm{H}-9), 4.82(d, J=12.0 \mathrm{~Hz}, 2 \mathrm{H}$, $\mathrm{H}-2 \mathrm{~d}$ and $\mathrm{H}-11 \mathrm{~d}) .{ }^{13} \mathrm{C}$ NMR $\left(100 \mathrm{MHz}, \mathrm{D}_{2} \mathrm{O}\right) \delta$ (ppm): 41.9 (C-12), 55.3 (C-4 and C-5), 69.1 (C-7 and C-10), 79.0 (C-9), 80.5 (C-2 and C-11). MS (ESI $\left.{ }^{+}\right): m / z 169.1449$ $\left[\mathrm{C}_{7} \mathrm{H}_{14} \mathrm{~N}_{4}{ }^{+} \mathrm{CH}_{3}\right]$.

\section{1-ethyl-1,3,6,8-tetraazatricyclo[4.3.1.1 $1^{3,8}$ undecan-1-ium iodide (3b)}

Was isolated as a white solid hygroscopic, (0.270 g, $87 \%)$, M.p. $=120-121.0^{\circ} \mathrm{C}$ (decomposition), FT-IR $(\mathrm{KBr})$ $\nu_{\text {max }}: 2959,2937,1473,1454,1405,1387,1347,1321$, 1296, 1256, 1235, 1158, 1128, 1114, 1044, 1022, 993, 979, 965, 925, 881, 843, 813, 771, 737, 694, 656, 582, $529,497,471,455,423 \mathrm{~cm}^{-1} .{ }^{1} \mathrm{H}$ NMR $\left(400 \mathrm{MHz}, \mathrm{D}_{2} \mathrm{O}\right)$ $\delta(\mathrm{ppm}): 1.31(t, J=8.0 \mathrm{~Hz}, 3 \mathrm{H}, \mathrm{H}-13), 3.06(q, J=8.0$ $\mathrm{Hz}, 2 \mathrm{H}, \mathrm{H}-12), 3.44(s, 4 \mathrm{H}, \mathrm{H}-4$ and $\mathrm{H}-5), 4.00(d, J=$ $12.0 \mathrm{~Hz}, 2 \mathrm{H}, \mathrm{H}-7 \mathrm{a}$ and $\mathrm{H}-10 \mathrm{a}), 4.56(d, J=12.0 \mathrm{~Hz}, 2 \mathrm{H}$, $\mathrm{H}-7 \mathrm{~b}$ and $\mathrm{H}-10 \mathrm{~b}), 4.64(d, J=12.0 \mathrm{~Hz}, 2 \mathrm{H}, \mathrm{H}-2 \mathrm{c}$ and $\mathrm{H}-11 \mathrm{c}), 4.82$ ( $s, 2 \mathrm{H}, \mathrm{H}-9), 4.83(d, J=12.0 \mathrm{~Hz}, 2 \mathrm{H}, \mathrm{H}-2 \mathrm{~d}$ and $\mathrm{H}-11 \mathrm{~d}) .{ }^{13} \mathrm{C}$ NMR $\left(100 \mathrm{MHz}, \mathrm{D}_{2} \mathrm{O}\right) \delta(\mathrm{ppm}): 5.8$ (C-13), 51.8 (C-12), 55.3 (C-4 and C-5), 69.6 (C-7 and C-10), 77.9 (C-9), 78.2 (C-2 and C-11). MS (ESI $\left.{ }^{+}\right): m / z$ $183.1587\left[\mathrm{C}_{7} \mathrm{H}_{14} \mathrm{~N}_{4}{ }^{+} \mathrm{C}_{2} \mathrm{H}_{5}\right]$.

\section{1-propyl-1,3,6,8-tetraazatricyclo[4.3.1.1 $\left.{ }^{3,8}\right]$ undecan-1-ium iodide (3c)}

Was isolated as a white solid hygroscopic, (0.292 g, 90\%), M.p. $=123.2-124^{\circ} \mathrm{C}$ (decomposition), FT-IR (KBr) $v_{\max }$ : 2957, 2935, 1459, 1402, 1389, 1345, 1324, 1260, 1226, 1161, 1112, 1049, 1033, 1009, 969, 948, 877, 814, 746, 655, 449, $423 \mathrm{~cm}^{-1} .{ }^{1} \mathrm{H}$ NMR (400 MHz, D $\left.2 \mathrm{O}\right) \delta(\mathrm{ppm})$ : $0.98(t, J=4.0 \mathrm{~Hz}, 3 \mathrm{H}, \mathrm{H}-14), 1.74(m, J=4.0 \mathrm{~Hz}, 2 \mathrm{H}, \mathrm{H}-$ 13), $2.91(m, J=4.0 \mathrm{~Hz}, 2 \mathrm{H}, \mathrm{H}-12), 3.43(s, 4 \mathrm{H}, \mathrm{H}-4$ and $\mathrm{H}-5), 4.00(d, J=16.0 \mathrm{~Hz}, 2 \mathrm{H}, \mathrm{H}-7 \mathrm{a}$ and H-10a), 4.56 (d, $J=16.0 \mathrm{~Hz}, 2 \mathrm{H}, \mathrm{H}-7 \mathrm{~b}$ and $\mathrm{H}-10 \mathrm{~b}), 4.64(d, J=12.0 \mathrm{~Hz}$, $2 \mathrm{H}, \mathrm{H}-2 \mathrm{c}$ and $\mathrm{H}-11 \mathrm{c}), 4.83$ ( $s, 2 \mathrm{H}, \mathrm{H}-9), 4.84(d, J=12.0$ $\mathrm{Hz}, 2 \mathrm{H}, \mathrm{H}-2 \mathrm{~d}$ and $\mathrm{H}-11 \mathrm{~d}) .{ }^{13} \mathrm{C}$ NMR $\left(100 \mathrm{MHz}, \mathrm{D}_{2} \mathrm{O}\right) \delta$ (ppm): 10.6 (C-14), 14.0 (C-13), 55.3 (C-4 and C-5), 58.0 (C-12), 69.6 (C-7 and C-10), 78.2 (C-9), 78.7 (C-2 and C11). MS $\left(\mathrm{ESI}^{+}\right): m / z 197.1730\left[\mathrm{C}_{7} \mathrm{H}_{14} \mathrm{~N}_{4}{ }^{+} \mathrm{C}_{3} \mathrm{H}_{7}\right]$.

\section{1-butyl-1,3,6,8-tetraazatricyclo[4.3.1.1 $\left.1^{3,8}\right]$ undecan-1-ium iodide (3d)}

Was isolated as a white solid hygroscopic, (0.287 g, $85 \%)$, M.p. $=127.2-128.1^{\circ} \mathrm{C}$ (decomposition), FT-IR $(\mathrm{KBr}) \nu_{\max }: 2964,2931,2871,1462,1403,1359,1338$, 1312 , 1261, 1222, 1160, 1143, 1112, 1049, 1029, 1006,
973, 938, 886, 856, 814, 780, 736, 653, 528, $453 \mathrm{~cm}^{-1} \cdot{ }^{1} \mathrm{H}$ NMR (400 MHz, $\left.\mathrm{D}_{2} \mathrm{O}\right) \delta(\mathrm{ppm}): 0.93(t, J=8.0 \mathrm{~Hz}, 3 \mathrm{H}$, $\mathrm{H}-15), 1.34(m, J=8.0 \mathrm{~Hz}, 2 \mathrm{H}, \mathrm{H}-14), 1.67(m, J=8.0$ $\mathrm{Hz}, 2 \mathrm{H}, \mathrm{H}-13), 2.92(m, J=8.0 \mathrm{~Hz}, 2 \mathrm{H}, \mathrm{H}-12), 3.40(s$, $4 \mathrm{H}, \mathrm{H}-4$ and $\mathrm{H}-5), 3,96(d, J=12.0 \mathrm{~Hz}, 2 \mathrm{H}, \mathrm{H}-7 \mathrm{a}$ and $\mathrm{H}-10 \mathrm{a}), 4.52$ (d, $J=12.0 \mathrm{~Hz}, 2 \mathrm{H}, \mathrm{H}-7 \mathrm{~b}$ and H-10b), 4.61 $(d, J=12.0 \mathrm{~Hz}, 2 \mathrm{H}, \mathrm{H}-2 \mathrm{c}$ and $\mathrm{H}-11 \mathrm{c}), 4.83$ (s, 2H, H-9), $4.85(d, J=12.0 \mathrm{~Hz}, 2 \mathrm{H}, \mathrm{H}-2 \mathrm{~d}$ and $\mathrm{H}-11 \mathrm{~d}) .{ }^{13} \mathrm{C}$ NMR (100 MHz, $\left.\mathrm{D}_{2} \mathrm{O}\right) \delta$ (ppm): 12.9 (C-15), 19.8 (C-14), 22.1 (C-13), 55.3 (C-4 and C-5), 56.3 (C-12), 69.6 (C-7 and C-10), 78.2 (C-9), 78.6 (C-2 and C-11). MS (ESI $\left.{ }^{+}\right): m / z$ $211.1923\left[\mathrm{C}_{7} \mathrm{H}_{14} \mathrm{~N}_{4}{ }^{+} \mathrm{C}_{4} \mathrm{H}_{9}\right]$.

\section{1-pentyl-1,3,6,8-tetraazatricyclo[4.3.1.1 ${ }^{3,8}$ undecan-1-ium iodide (3e)}

Was isolated as a white solid hygroscopic, (0.306 g, $87 \%)$, M.p. $=130.0-131.5^{\circ} \mathrm{C}$ (decomposition), FT-IR (KBr) $v_{\text {max }}$ : 2953, 2922, 2867, 1464, 1403, 1341, 1313, 1291, 1263, 1238, 1161, 1144, 1099, 1050, 1032, 976, 938, 903, 888, 814, 728, 653, 528, $451 \mathrm{~cm}^{-1} .{ }^{1} \mathrm{H}$ NMR (400 MHz, $\left.\mathrm{D}_{2} \mathrm{O}\right) \delta(\mathrm{ppm}): 0.89(t, J=8.0 \mathrm{~Hz}, 3 \mathrm{H}, \mathrm{H}-16)$, $1.33(m, J=8.0 \mathrm{~Hz}, 4 \mathrm{H}, \mathrm{H}-15$ and $\mathrm{H}-14), 1.68(m, J=$ $8.0 \mathrm{~Hz}, 2 \mathrm{H}, \mathrm{H}-13), 2.91(t, J=8.0 \mathrm{~Hz}, 2 \mathrm{H}, \mathrm{H}-12), 3.40$ $(s, 4 \mathrm{H}, \mathrm{H}-4$ and $\mathrm{H}-5), 3.97(d, J=16.0 \mathrm{~Hz}, 2 \mathrm{H}, \mathrm{H}-7 \mathrm{a}$ and H-10a), $4.52(d, J=16.0 \mathrm{~Hz}, 2 \mathrm{H}, \mathrm{H}-7 \mathrm{~b}$ and $\mathrm{H}-10 \mathrm{~b})$, $4.61(d, J=12.0 \mathrm{~Hz}, 2 \mathrm{H}, \mathrm{H}-2 \mathrm{c}$ and $\mathrm{H}-11 \mathrm{c}), 4.80(s, 2 \mathrm{H}$, $\mathrm{H}-9), 4.81(d, J=12.0 \mathrm{~Hz}, 2 \mathrm{H}, \mathrm{H}-2 \mathrm{~d}$ and $\mathrm{H}-11 \mathrm{~d}) .{ }^{13} \mathrm{C}$ NMR (100 MHz, D $2 \mathrm{O}) \delta(\mathrm{ppm}): 13.2$ (C-16), 19.7 (C15), 21.5 (C-14), 28.3 (C-13), 55.3 (C-4 and C-5), 56.5 (C-12), 69.6 (C-7 and C-10), 78.2 (C-9), 78.7 (C-2 and C-11). MS (ESI $\left.{ }^{+}\right): m / z 225.2120\left[\mathrm{C}_{7} \mathrm{H}_{14} \mathrm{~N}_{4}{ }^{+} \mathrm{C}_{5} \mathrm{H}_{11}\right]$.

\section{1-hexyl-1,3,6,8-tetraazatricyclo[4.3.1.1 $\left.1^{3,8}\right]$ undecan-1-ium iodide (3f)}

Was isolated as a white solid hygroscopic, (0.330 g, 90\%), M.p. $=133-134^{\circ} \mathrm{C}($ decomposition $)$, FT-IR $(\mathrm{KBr})$ $\nu_{\text {max }}: 2957,2935,2874,1459,1407,1389,1345,1321$, $1264,1225,1163,1110,1046,1031,1007,971,942,879$, 819, 783, 743, 655, $449 \mathrm{~cm}^{-1} .{ }^{1} \mathrm{H}$ NMR (400 MHz, $\left.\mathrm{D}_{2} \mathrm{O}\right)$ $\delta$ (ppm): $0.96(t, J=8.0 \mathrm{~Hz}, 3 \mathrm{H}, \mathrm{H}-17), 1.39(m, J=8.0$ $\mathrm{Hz}, 6 \mathrm{H}, \mathrm{H}-16, \mathrm{H} 15$ and $\mathrm{H}-14), 1.72(m, J=8.0 \mathrm{~Hz}, 2 \mathrm{H}$, $\mathrm{H}-13$ ), 2.89 ( $t, J=8.0 \mathrm{~Hz}, 2 \mathrm{H}, \mathrm{H}-12), 3.40$ (bs, $4 \mathrm{H}, \mathrm{H}-4$ and $\mathrm{H}-5), 3.93(d, J=12.0 \mathrm{~Hz}, 2 \mathrm{H}, \mathrm{H}-7 \mathrm{a}$ and $\mathrm{H}-10 \mathrm{a})$, $4.54(d, J=12.0 \mathrm{~Hz}, 2 \mathrm{H}, \mathrm{H}-7 \mathrm{~b}$ and $\mathrm{H}-10 \mathrm{~b}), 4.65$ (d, $J=$ $8.0 \mathrm{~Hz}, 2 \mathrm{H}, \mathrm{H}-2 \mathrm{c}$ and $\mathrm{H}-11 \mathrm{c}), 4.85$ (s, 2H, H-9), 4.86 (d, $J=8.0 \mathrm{~Hz}, 2 \mathrm{H}, \mathrm{H}-2 \mathrm{~d}$ and $\mathrm{H}-11 \mathrm{~d}) .{ }^{13} \mathrm{C}$ NMR $(100 \mathrm{MHz}$, $\left.\mathrm{D}_{2} \mathrm{O}\right) \delta(\mathrm{ppm}): 10.8$ (C-17), 18.0 (C-16), 20.0 (C-15), 24.2 (C-14), 28.8 (C-13), 55.3 (C-12, C-4 and C-5), 69.7 (C-7 and C-10), 78.6 (C-9), 78.7 (C-2 and C-11). MS $\left(\mathrm{ESI}^{+}\right): m / z 239.2291\left[\mathrm{C}_{7} \mathrm{H}_{14} \mathrm{~N}_{4}{ }^{+} \mathrm{C}_{6} \mathrm{H}_{13}\right]$.

\section{Single crystal X-ray measurements}

Crystal data for compound $\mathbf{3 b}, \mathrm{C}_{9} \mathrm{H}_{19} \mathrm{~N}_{4}$.I, were collected using a Xcalibur Atlas Gemini ultra diffractometer of 
Oxford Diffraction equipped with Mo tube with graphite monochromator, Mo-Enhanced fiber-optics collimator and CCD detector Atlas. $\mathrm{M}=310.2$, trigonal, $R 3, \mathrm{a}=$ 12.8935(3), $\mathrm{b}=12.8935(3), \mathrm{c}=18.4328(4) \AA, \mathrm{V}=2653.8$ (1) $\AA^{3}, Z=9$, Dcalcd $=1.746 \mathrm{~g} / \mathrm{cm}^{3}, X$-ray source Mo Ka radiation, $\mathrm{k}=0.7107 \AA, \mathrm{F}\left(\begin{array}{ll}0 & 0\end{array}\right)=1386$, colorless prism $0.42 \times 0.34 \times 0.25 \mathrm{~mm}$. All non-hydrogen atoms were refined with anisotropic thermal parameters, and hydrogen atoms of carbons were kept in an ideal geometry. Isotropic ADP of all hydrogen atoms were fixed as a 1.2 multiple of the $U_{e q}$ of the parent atom. Crystallographic data (excluding structural factors) have been deposited at the Cambridge Crystallographic Data Centre (CCDC). Copies of the data can be obtained free of charge by writing to the CCDC, 12 Union Road, Cambridge CB2 IEZ, UK. Fax: +44-(0)1223-336033 or e-mail: deposit@ccdc. cam.ac.uk. The CCDC deposition number is CCDC 823082 .

\section{Computational details}

Calculations were performed using the Gaussian 98 package [20]. The Fukui indices were determined, as described by Yang and Mortier [22].

\section{Acknowledgements}

We acknowledge the Dirección de Investigación Sede Bogotá (DIB) of Universidad Nacional de Colombia for financial support and the Institutional Research Plan No. AVOZ10100521 of the Institute of Physics and the Project Praemium Academiae of the Academy of Sciences of the Czech Republic. Also, J. S-B. is grateful for a scholarship from Facultad de Ciencias, Universidad Nacional de Colombia.

\section{Author details}

'Departamento de Química, Universidad Nacional de Colombia, Ciudad Universitaria, Carrera 30 No. 45-03, Bogotá D.C., Colombia. ${ }^{2}$ Institute of Physics ASCR, v.vi.., Na Slovance 2, 18221 Praha 8, Czech Republic.

\section{Authors' contributions}

$J S-B$ and JR-M synthesized the title compounds under the guidance of AR. LP collected the X-ray data and solved the crystal structures under the guidance of MD. All the authors read and approved the final manuscript.

\section{Competing interests}

The authors declare that they have no competing interests.

Received: 23 August 2011 Accepted: 20 September 2011 Published: 20 September 2011

\section{References}

1. Rivera A, Núñez ME, Morales-Ríos MS, Joseph-Nathan P: Preparation of cage amine 1,3,6,8-tetraazatricyclo[4.3.1.1.18 $]$ undecane. Tetrahedron Lett 2004, 45:7563-7565.

2. Rivera A, González-Salas D, Ríos-Motta J, Hernández-Barragán A, JosephNathan P: Preferred hydrogen bonding site of 1,3,6,8-tetraazatricyclo [4.3.1.1 $\left.{ }^{3,8}\right]$ undecane (TATU) to hydroquinone. J Mol Struct 2007, 837:142-146.

3. Rivera A, Nuñez ME, Avella E, Rios-Motta J: An NMR study of sequential intermediates and collateral products in the conversion of $1,3,6,8$ tetraazatricyclo[4.4.1.1 $1^{3,8}$ ]dodecane (TATD) to 1,3,6,8-tetraazatricyclo [4.3.1.1 $1^{3,8}$-undecane (TATU). Tetrahedron Lett 2008, 49:2154-2158.
4. Rivera A, Moyano D, Maldonado M, Ríos-Motta J, Reyes A: FT-IR and DFT studies of the proton affinity of small aminal cages. Spectrochimica Acta Part A 2009, 74:588-590.

5. Rivera A, González-Salas D: Synthesis and characterization of novel triazenes from the reaction of the cyclic aminal 1,3,6,8-tetraazatricyclo [4.3.1.1 $1^{3,8}$ ]undecane (TATU) with diazonium ions. Tetrahedron Lett 2010, 51:2500-2504.

6. Rivera A, Sadat-Bernal J, Ríos-Motta J, Dušek M, Fejfarová K: Structural consequences of anomeric effect in 1,3,6,8-tetraazatricyclo[4.3.1.1.3,8] undecan-1-ium pentachlorophenolate monohydrate. J Chem Crystallogr 2011, 41:591-595.

7. Patai S: The Chemistry of the Functional Groups, Supplement F: The Chemistry of amino, nitroso and nitro compounds and their derivatives, Part 2 John Wiley \& Sons, Inc., Chichester, UK; 1982.

8. Kazantsev OA, Baruta DS, Shirshin KV, Sivokhin AP, Kamorin DM: Concentration effects in the nucleophilic reactions of tertiary amines in aqueous solutions. Alkylation of amines with ethylene chlorohydrin. Russ J Phys Chem A 2010, 84:2071-2076.

9. Hati S, Datta D: Anomeric effect and hardness. J Org Chem 1992, 57:6056-6057.

10. Sélambarom J, Monge S, Carré F, Fruchier A, Roque JP, Pavia AA: Contribution of the anomeric effect to the solution and crystal structure of [1S,2S,6S,7S]-1,6-diaza-4,9-dioxa-2,7-dimethoxycarbonylbicyclo[4.4.1] undecane, a condensation product of L-serine methyl ester with formaldehyde. Carbohyd Res 2001, 330:43-51.

11. Alder RW, Carniero TMG, Mowlam RW, Orpen AG, Petillo PA, Vachon DJ, Weisman GR, White JM: Evidence for hydrogen-bond enhanced structural anomeric effects from the protonation of two aminals, 5-methyl-1,5,9triazabicyclo[7.3.1]tridecane and 1,4,8,11-tetraazatricyclo[9.3.1.1. ${ }^{4,8}$ ] hexadecane. J Chem Soc Perkin Tran 2 1999, 589-599.

12. Kakanejadifard A, Farnia SMF: Synthesis and X-ray structural determination of new aniline derivatives of 2,4,6,8-tetraazabicyclo[3.3.0]octanes; Anomeric effect in N-C-N moiety and implications of solvent polarity on ${ }^{1} \mathrm{H}-\mathrm{NMR}$ patterns. Tetrahedron 1997, 53:2551-2556.

13. Starks CM: Phase-transfer catalysis. I. Heterogeneous reactions involving anion transfer by quaternary ammonium and phosphonium salts. J Am Chem Soc 1971, 93:195-199.

14. Chong KCW, Sivaguru J, Shichi T, Yoshimi Y, Ramamurthy V, Scheffer JR: Use of chirally modified zeolites and crystals in photochemical asymmetric synthesis. J Am Chem Soc 2002, 124:2858-2859.

15. Khramov DM, Bielawski CW: Donor-acceptor triazenes: Synthesis, Characterization, and study of their electronic and thermal properties. $J$ Org Chem 2007, 72:9407-9417.

16. Tang T, Coady DJ, Boydston AJ, Dykhno OL, Bielawski CW: Pro-lonomers: An anion metathesis approach to amphiphilic block ionomers from neutral precursors. Adv Mater 2008, 20:3096-3099.

17. Khramov DM, Lynch VM, Bielawski CW: Heterocyclic carbine-transition metal complex: Spectroscopic and crystallographic analyses of $\pi$-backbonding interactions. Organometallics 2007, 26:6042-6049.

18. Singh RP, Verma RD, Meshri DT, Shreeve JM: Energetic nitrogen-rich salts and ionic liquids. Angew Chem Int Ed 2006, 45:3584-3601.

19. Murray-Rust P: Crystal and molecular structure of 1,3,6,8-tetraazatricyclo [4.4.1.1 ${ }^{3,8}$ ]dodecane, the 2:1 condensation product of formaldehyde and 1,2-diaminoethane, and the conformation of this system. J Chem Soc Perkin Trans 2 1974, 1136-1141.

20. Frisch MJ, Trucks GW, Schlegel HB, Scuseria GE, Robb MA, Cheeseman JR, Zakrzewski VG, Montgomery JA Jr, Stratmann RE, Burant JC, Dapprich S, Millam JM, Daniels AD, Kudin KN, Strain MC, Farkas O, Tomasi J, Barone V, Cossi M, Cammi R, Mennucci B, Pomelli C, Adamo C, Clifford S, Ochterski J, Petersson GA, Ayala PY, Cui Q, Morokuma K, Malick DK, Rabuck AD, Raghavachari K, Foresman JB, Cioslowski J, Ortiz JV, Baboul AG, Stefanov BB, Liu G, Liashenko A, Piskorz P, Komaromi I, Gomperts R, Martin RL, Fox DJ, Keith T, Al-Laham MA, Peng CY, Nanayakkara A, Challacombe M, Gill PMW, Johnson B, Chen W, Wong MW, Andres JL, Gonzalez C, Head-Gordon M, Replogle ES, Pople JA: GAUSSIAN 98 (Revision A9). Gaussian Inc Pittsburgh: PA; 1998.

21. Glister JF, Vaughan K, Biradha K, Zaworotko MJ: (2S,7R,11S,16R)-1,8,10,17tetraazapentacyclo-[8.8.1.1 $\left.1^{8,17} \cdot 0^{2,7} \cdot 0^{11,16}\right]$ icosane and its enantiomer. Synthesis, NMR analysis and X-ray crystal structure. J Mol Struct 2005, 749:78-83. 
22. Yang W, Mortier WJ: The use of global and local molecular parameters for the analysis of the gas-phase basicity of amines. J Am Chem Soc 1986, 108:5708-5711.

doi:10.1186/1752-153X-5-55

Cite this article as: Rivera et al: Synthesis and structural studies of a new class of quaternary ammonium salts, which are derivatives of cage adamanzane type aminal 1, 3, 6, 8-tetraazatricyclo[4.3.1.1 ${ }^{3,8}$ undecane (TATU). Chemistry Central Journal 2011 5:55.

\footnotetext{
Publish with ChemistryCentral and every scientist can read your work free of charge

"Open access provides opportunities to our colleagues in other parts of the globe, by allowing anyone to view the content free of charge." W. Jeffery Hurst, The Hershey Company.

- available free of charge to the entire scientific community

- peer reviewed and published immediately upon acceptance

- cited in PubMed and archived on PubMed Central

- yours - you keep the copyright

Submit your manuscript here:

hubmit your manuscript here:
http://www.chemistrycentral.com/manuscript/<smiles>c1ccccc1</smiles> 